\title{
The role of education in explaining technology- intensive exports: a comparative analysis of transition and non-transition economies
}

\author{
Arta MULLIQI*
}

\begin{abstract}
This article examines the role of education in explaining the technology-intensive exports of 27 European countries. A comparative analysis of transition and nontransition economies is also conducted in this article. The empirical assessment provides sufficient evidence to support the hypothesized positive link between the stock of population with tertiary education and the share of medium-high and hightechnology exports for the full sample of countries, the effect being relatively stronger for the high-technology category. The importance of higher levels of education is further supported by the non-linear relationship between the average years of schooling and technology intensive exports. The empirical findings also reveal a positive and highly significant relationship between the share of population with tertiary education and the export sophistication of the full set of countries. The evidence from country group estimations is weaker. Some supporting evidence is found for the hypothesized role of the quality of education.
\end{abstract}

Keywords: technology-intensive exports, education attainment, quality of education, transition economies

\section{Introduction}

The importance of fully participating in international markets for a country's economic development has been established in the literature. Over the transition period, the majority of countries in Central and Eastern Europe have managed to increase their engagement in international markets and in turn enhance their international competitiveness. This transition and integration process has involved significant shifts in the composition of exports, with some of these countries having managed to switch their focus from low skill and technology goods to a more sophisticated basket of exports. Given the rapidly increasing global demand for these

\footnotetext{
*Arta MULLIQI is an Assistant Professor of Economics at UBT College, Pristina, Kosovo; e-mail: artamulliqi@gmail.com.
} 
products (Rodrik, 2006; Hausmann et al., 2007; Jarreau and Poncet, 2012; Anand et al., 2012), highly sophisticated and technology-intensive exports are considered a key source of sustainable economic growth and international competitiveness. According to Hausmann et al. (2007), what rather than how much countries export is likely to matter more for future economic development and growth. In other words, focusing on products that rich countries export, keeping everything else unchanged, tends to have a stronger impact on growth compared to specializing in other (less sophisticated) goods (Hausmann et al., 2007).

The change in the compositional structure of exports in transition economies, and their convergence towards the typical structure of high income countries is central to this research. Particular attention is paid to the high-technology exports and their evolution during the course of transition. The data extracted from the World Bank, World Development Indicators show an overall positive trend in hightechnology goods in these countries. On average, total high-technology ${ }^{1}$ exports appear to have increased in most transition economies, though; the rates of change are not uniform across them ${ }^{2}$. This has also been associated with an increased share of high-technology exports in the total manufactured exports. Between 1996 and 2017, European transition economies experienced, on average, an increase of 95 percent in their share of high technology exports ${ }^{3}$. Countries with the highest hightechnology export shares recorded in 2017 were Latvia and Estonia with rates of $16 \%$, with the Western Balkan region being positioned at the lower end of the ranking. However, in spite of this growth, there are still striking differences between their export structure and that of the EU-18 ${ }^{4}$. This further reinforces the importance of assessing the potential determinants of their diverse export baskets, with a special focus on the role of education. A regression analysis examining the impact of education on the international competitiveness of 27 European countries in technology-intensive goods, with particular emphasis on comparing transition and non-transition economies is conducted in this paper.

In order to be able to meet the upgraded labour market's needs, transition economies started to reform their educational systems. The shift in demand towards more highly educated employees has been accompanied by an expansion of the higher education sector in the majority of these countries (Barro and Lee, 2014;

\footnotetext{
${ }^{1}$ According to the World Bank, High-technology exports are products with high R\&D intensity, such as in aerospace, computers, pharmaceuticals, scientific instruments, and electrical machinery.

${ }^{2}$ World Bank (2019a), High-technology exports, current US\$.

${ }^{3}$ World Bank (2019b), High-technology exports \% of manufactured exports.

${ }^{4}$ The EU-18 has, on average, experienced a negative trend in high technology exports since early 2000s though there are significant variations across the region, with some of the countries experiencing positive or lower negative rates as compared to others (World Bank, 2019b).
} 
World Bank $^{5}$ ). A rapid expansion was recorded in the attainment of tertiary education of the population aged 15 and over although there is a considerable variation across the region. This was also reflected in increases in the average years of total schooling of the population aged 15 and over, i.e. from 9.2 in 1990 to 11.2 in 2010 (Barro and Lee, 2014). However, despite the rapid growth of the stock of population with tertiary education, the issue of skill mismatch appears to be prevalent in the transition region. This is also accompanied by skill shortages, particularly in the fields of science, technology, and engineering (Arias et al., 2014).

In a previous study by Mulliqi et al. (2018), tertiary education was found to exert a positive and significant impact on the export market share of the European Economic Area (EEA17), whereas the effect of the stock of population with secondary education was larger in the sample of transition economies of Central and Eastern Europe. The different stages of economic development of these countries and their distinct export structures were highlighted as potential reasons for these differences. That is to say, there is a tendency among developed countries to export more sophisticated, technology-intensive goods, with less advanced economies being more involved in exporting less skill and technology intensive goods. On the relationship between human capital and technological knowledge, Rosenzweig $(1995,1996)$ postulates that specific types of skills are mostly useful when combined with specific technologies. In line with this, a higher level of education attained is more likely to enhance the productivity of workers when more advanced activities are to be performed.

With the purpose of modelling and testing the relative importance of a country's stock of educated labour force on its international competitiveness in technology intensive goods, a country-industry level analysis using medium-high and high technology export data for the period 1995-2010 is conducted in this paper. Firstly, a regression analysis examining the impact of different measures of education on technology-intensive exports of 27 European countries is conducted. Secondly, special emphasis is placed on testing whether the hypothesized impact of education is relatively stronger for higher technology goods. Finally, this paper addresses whether differences in the stock of educated labour force between transition and non-transition economies can explain their different levels of technology intensive export shares and export sophistication. This paper employs a comprehensive set of measures of international competitiveness and education, as well as a set of control variables. International competitiveness is proxied by the share of medium-high and high technology exports and by an export sophistication index, whereas education is captured by the share of population who have attained secondary and tertiary education, the average years of schooling, and three alternative measures of the quality of education.

\footnotetext{
${ }^{5}$ World Bank (2016), Labour force with primary/secondary/tertiary education (\% of total) database.
} 
The empirical assessment makes several contributions to knowledge. The relationship between education and technology-intensive exports has not been well researched in the context of transition economies. Studies assessing the importance of education for international competitiveness have mainly focused on education attainment while no attention has been paid to the role of the quality of education (see Mulliqi et al., 2018, for an exception). To fill this void, in addition to examining the impact of the share of population with secondary and tertiary education, this study also takes into account the quality of education. To ensure the robustness of the results, three alternative measures of quality are employed in the estimations. Another novelty of this paper is the assessment of the relative importance of education for different levels of technological intensity. To account for the presence of endogenous variables in the model, a Fixed Effects Instrumental Variable approach is adopted. Furthermore, to be able to capture the effects of time constant and slowly changing variables, two estimators, Fixed Effects Vector Decomposition and Hausman and Taylor are used. Given the differences in the technology intensity of their export baskets, this study provides a comparative analysis of transition and non-transition economies in terms of the hypothesized impact of education on technology intensive export share, and export sophistication.

For the full sample of countries, in line with the theoretical basis, a positive association between the stock of population with tertiary education and the share of medium-high and high-technology exports is found. When differentiating between medium - high and high technology exports, the impact of the share of population with tertiary educated, as anticipated, is stronger in the latter category. The importance of higher levels of education is also supported by the non-linear relationship between average years of schooling and technology intensive exports. Similar results are found when international competitiveness is proxied by the export sophistication index. As opposed to the full sample findings, the country group evidence is relatively weaker. Some supporting evidence is found for the hypothesized importance of the education quality.

The remainder of this article is organized as follows: section 1 provides the theoretical basis for this investigation and a review of previous empirical research. Section 2 describes the model specifications, data sources, and estimation methodologies. The following section reports and interprets the estimation findings. The last section summarizes the main results and examines policy implications.

\section{Literature review}

It was the new endogenous growth theory that emphasized the key importance of human capital investment for the economic performance of nations. Proponents of this view argue that skilled individuals are more likely to innovate and/or adopt new sophisticated technologies, which consequently increases productivity and generates growth (Nelson and Phelps, 1966; Lucas, 1988; Romer, 1990). Similar to the human 
capital - growth mechanisms, the importance of human capital accumulation for competitiveness and export performance is generally derived from its relation with technological diffusion and catch-up, innovation and labour productivity.

The potential link between human capital and labour productivity, with particular focus on the main sources of human capital accumulation has been assessed by various schools of thought, one of the most prominent being the orthodox human capital theory. Becker (1964), one of its main contributors, considers education as a key source of human capital development, as it is expected to develop the learning abilities of individuals, which, in turn, tend to translate into higher labour productivity. Regarding the transmission mechanism, the influence of skills and knowledge on productivity seems to also depend on the set of tasks to be performed. According to Rosenzweig $(1995,1996)$, education is likely to have a greater impact on productivity when more learning is required to perform complex tasks whereas the effect will be relatively smaller when simpler tasks are to be performed.

An important aspect that has started to increasingly attract the interest of researchers is the potential impact of human capital on the quality of exports of a country. According to Cavallaro et al. (2012), skilled human capital represents a key source of higher product quality and technological catch-up with more advanced economies. In their assessment of export diversification and sophistication, Cabral and Veiga (2010) found supporting evidence for the positive role of the educational level of the workforce on both dimensions, the impact being relatively stronger on the latter. To capture the "quality" or "sophistication" of a country's export basket, Hausmann et al. (2007) developed an export sophistication index. While human capital turned out to be positively correlated with export sophistication, the causality direction was not well established. According to Anand et al. (2012), the education level of the workforce represents a key precondition to producing and exporting higher quality/sophisticated goods and services. The results of their research revealed a positive association between the years of schooling in tertiary education, total years of schooling and export sophistication. Similarly, Zhu et al. (2009) found supporting evidence for the positive impact of the gross tertiary enrolment rate on export sophistication. Using educational expenditure as a proxie, Huseyni and Cakmak (2019) also found a positive link between human capital and export sophistication. Jarreau and Poncet (2009) and Weldemicael (2012) generated similar findings. An insignificant relationship between gross tertiary enrolment and export sophistication, on the other hand, was suggested by Kočenda and Poghosyan (2018).

The share of medium and high technology exports has frequently been used to capture the quality or sophistication level of exports. An empirical analysis undertaken by Srholec (2007) for a group of 111 developing countries revealed supporting evidence for the positive impact of gross tertiary enrolment on a country's specialization in high-technology products. A positive association between the stock of human capital, and export specialization in ICT products was also found in a study conducted by Vogiatzoglou (2009). Similarly, Ferragina and Pastore (2007) 
investigated the impact of human capital on the high technology exports of 84 countries for the period 1994-2003. According to their empirical assessment, human capital, proxied by secondary school enrolments, exerts a positive impact on the share of high technology exports. In his panel analysis, Tebaldi (2011) suggests a positive association between the average years of schooling and high technology exports. The positive effect of human capital on the share of high technology exports of 15 EU countries during 1995-2010 was also established through a cointegration analysis conducted by Gökmen and Turen (2013). The importance of human capital in explaining the performance of high technology exports has also been recently concluded on by Güneş et al. (2020).

It is pertinent to note that most of these studies make no explicit reference to transition economies. International competitiveness has been poorly approximated by absolute rather than relative measures. While there are many proxies of international competitiveness used in the literature, most of these might be regarded as simple measures of a country's wellbeing and economic success, which do not reflect its relative competitive position in the global economy. The international competitiveness is expected to measure the competitive position of a country in relation to a region or the world. Namely, if the technology intensive exports of a country increase at a higher rate than the technology intensive exports of other countries, it can be argued that its relative position has improved, and vice-versa. Hence, this paper focuses on a country's export share of technology intensive relative to EU-28. Another limitation of previous research relates to appropriately capturing the broad dimensions of human capital. While various measures related to the quantity of education have been employed, the quality of education as a key dimension of human capital has rarely been tested in previous studies. Another shortcoming of the vast majority of studies is their failure to investigate potential sources of endogeneity. In many cases, potential reverse causation between education and exports is not discussed and/or no robustness checks are undertaken to determine the direction of causality. Hence, an important element of this research is identifying and addressing potential endogeneity in the estimations.

\section{Model specification and estimation methodology}

In order to assess the relative competitiveness of a sample of $27^{6}$ European countries in exporting medium-high and high-technology manufactures, two distinct measures are adopted: export market share and an export sophistication index.

\footnotetext{
${ }^{6}$ Countries included in the sample are: Austria, Belgium, Bulgaria, Cyprus, Czech Republic, Denmark, Germany, Estonia, Finland, France, Greece, Hungary, Ireland, Italy, Latvia, Lithuania, Luxembourg, the Netherlands, Norway, Poland, Portugal, Romania, Slovenia, Slovakia, Spain, Sweden, and the United Kingdom.
} 
Export market share is defined as the share of a country's exports in mediumhigh and high-technology industries in the exports of the same industries in the EU28, measured as percentages, for the period 1995-2010. As constructed, it is expected to reflect the degree of competitiveness of each country relative to this particular set of countries in medium-high and high technology manufacturing exports. The data used to construct this measure are taken from the OECD STAN Bilateral Trade Database by Industry and End-use category, based on the 2-digit level, ISIC revision 3 (OECD, 2013). This indicator is then re-constructed separately for medium-high and high technology exported goods ${ }^{7}$.

Export sophistication index measures the sophistication of a country's export basket. This index has been introduced by Hausmann et al. (2007) to capture the productivity level associated with a country's export portfolio. The index covers 89 product groups ${ }^{8}$ which have been classified by the Innovation Union Scoreboard (European Commission, 2011) as medium and high technology manufactures. The data used to construct this measure are taken from UNCTAD's database: Merchandise trade matrix - detailed products, exports in thousands of dollars, annual, 1995-2013, SITC revision 3 (UNCTAD, 2014).

Education as the key component of interest is proxied by both quantity (i.e. education attainment) and quality measures. Data on the share of population aged 15 and over who have attained secondary and tertiary education as their highest level are used in this empirical analysis (Barro and Lee, 2014). These indicators are constructed using survey and census data from UNESCO, Eurostat, and national sources at 5-year intervals for the period 1950-2010. An interpolation procedure has been adopted to fill the void for the periods in between. In an alternative model specification, the average years of schooling of the population 15 and over is also employed. To control for potential non-linearity, the squared term of this variable is also included in the estimations.

Constrained by the lack of more disaggregated data, the stock of human capital endowments employed in this analysis is measured at the national level. Building on the theoretical framework of Heckscher-Ohlin-Vanek, Corvers and Grip (1997) suggest that it is the factor endowments measured at the country level that are more likely to explain export patterns. Since countries tend to focus on exporting goods that

\footnotetext{
7 The medium-high classification covers the following categories: Chemicals excluding Pharmaceuticals (24, excluding 2423), Machinery and Equipment, n.e.c (29), Electrical Machinery and Apparatus, n.e.c. (31), Motor Vehicles, Trailers and Semi-Trailers (34), and Railroad and Transport Equipment, n.e.c $(352,359)$. The high tech classification refers to: Pharmaceuticals (2423), Office, Accounting and Computing Machinery (30), Radio, Television and Communication Equipment (32), Medical, Precision and Optical Instruments (33), and Aircraft and Spacecraft (353).

${ }^{8}$ SITC: 266, 267, 512, 513, 525, 533, 54, 553, 554, 562, 57, 58, 591, 593, 597, 598, 629, 653, $671,672,679,71,72,731,733,737,74,751,752,759,76,77,78,79,812,87,88$ and 891 .
} 
are produced using their abundant endowments, country-level characteristics are expected to play an important role in explaining their export patterns at a sectoral level.

In addition to the education attainment component, quality measures of education are also introduced to the regression analysis. Quality of education is represented by alternative measures of students' achievements on internationally comparable tests made available by Hanushek and Woessmann (2012) and Altinok et al. (2014). The quality indicator provided by Hanushek and Woessmann (2012) is constructed by integrating and standardizing students' test scores for the period 1964-2003. This cognitive skills measure is defined as the average test score in mathematics and science, from primary through end of secondary school, all years (scaled to the PISA scale divided by 100). Similarly, Altinok et al. (2014) constructed a measure covering student achievements in primary and secondary education for the period 1964-2003 (averaged across time). These two measures are used in alternative model specifications as a robustness check. In addition to the averaged measure, Altinok et al. (2014) also provided a panel dataset on students' performance on international tests for the period 1965-2010. This dataset is used to conduct a separate regression analysis, covering a slightly smaller sample ${ }^{9}$.

With the purpose of controlling for other factors likely to explain the competitiveness of countries in exporting highly sophisticated goods, a set of control variables has been introduced to the estimations. It has been established in previous research that innovation plays an important role in explaining technology intensive exports (Ferragina and Pastore, 2007; Zhu et al., 2009; Vogiatzoglou, 2009), hence its hypothesized impact is tested by employing the number of patent applications as a proxy. In line with the theoretical and empirical considerations, this variable is expected to exert a positive and significant impact. As previously discussed, the lack of suitable skills appears to be a persistent issue in many transition economies. The main rationale for accounting for this factor is that skill mismatches tend to hinder the competitiveness of countries in exporting quality goods. Constrained by the lack of more appropriate data, the skill and qualification mismatch, in the estimations, is represented by the long-term unemployment rate. The size of foreign direct investment represented by the inward foreign direct investment stock (as a \% of GDP) has been introduced to capture the anticipated spillover effects from foreign firms on the export sophistication of host economies. To control for the size of the economy, a measure of total population is included in the regression analysis ${ }^{10}$.

Another potential driver of a country's engagement in international markets is unit labour cost which, in this analysis, is proxied by a real unit labour cost index provided by Eurostat. Higher unit labour costs decrease the competitiveness of

\footnotetext{
${ }^{9}$ Since data is available at intervals, linear interpolation has been used to fill the gaps in between.

${ }^{10}$ GDP per capita was initially included in the regression analysis, however, due to high multicollinearity issues, it was excluded from the final estimations.
} 
countries relative to their counterparts, thus reducing their presence in international markets. The hypothesized importance of the geographical characteristics of a country for its share of technology intensive exports will be assessed through the use of a distance measure. A greater distance to exporting markets implies higher shipping costs and longer transportation procedures (Behar and Venables, 2010). The ease of access to the main EU markets is represented by distance from each country's capital city to Brussels.

Given the focus of this research paper, a transition indicator and a transition dummy have been introduced to the regression analysis. The transition indicator represents a country's progress in transition, covering large scale privatization, small scale privatization, governance and enterprise restructuring, price liberalization, trade and foreign exchange system, and competition policy (EBRD, 2014). The transition dummy equals one if a country has gone through the transition process and zero otherwise $^{11}$. The potential impact of the economic freedom level of a country is captured by an equal weight index covering property rights, freedom from corruption, fiscal freedom, government spending, business freedom, labour freedom, and monetary freedom. A higher share of services in a country, holding everything else fixed, is likely to reduce its propensity to export technology intensive goods. Hence, the size of the non-tradable sector in the analysis is captured by a World Bank measure, defined as the value added in wholesale and retail trade, transport, and government, financial, professional, personal services and real estate services (as a $\%$ of GDP) ${ }^{12}$. Variable descriptions are presented in Table A1, in the appendix.

Guided by the theoretical framework discussed above and previous research, two main model specifications are estimated in this paper: Model Specification 1 focuses on the impact of the stock of population (15 and over) with secondary and tertiary education as their highest level attained while Model Specification $\mathbf{2}$ assesses the effect of average years of schooling on the share of technology intensive exports. Both model specifications account for the role of the quality of education which is proxied by three alternative measures (cognitive_skills, student_scores, and student_performance $)^{13}$. In addition to the variables of interests, the model specifications are augmented by sets of control variables and time dummies.

\footnotetext{
11 These two measures are not estimated together. The transition indicator is included in the TEs sample only, whereas the effect of the transition dummy is quantified in the full sample analysis.

${ }^{12}$ World Bank (2016), Labour force with primary/secondary/tertiary education (\% of total) database.

13 The three measures of the quality of education are included in alternative model specifications.
} 


\section{Model Specification 1:}

$\mathrm{Y}_{\mathrm{ikt}}=\beta_{1}$ secondary_educ $_{\mathrm{it}}+\beta_{2}$ tertiary_educ $_{\mathrm{it}}+\beta_{3}$ quality_educ $_{\mathrm{it}}+\delta$ controls $_{\mathrm{it}}+\alpha_{\mathrm{ik}}+\varepsilon_{\mathrm{it}}$

\section{Model Specification 2:}

$\mathrm{Y}_{\mathrm{ikt}}=\beta_{1}$ school_years ${ }_{\mathrm{it}}+\beta_{2}$ school_years $^{\wedge} 2_{\mathrm{it}}+\beta_{3}$ quality_educ ${ }_{\mathrm{it}}+\delta$ controls $_{\mathrm{it}}+\alpha_{\mathrm{ik}}+\varepsilon_{\mathrm{it}}$

Where $Y_{i k t}$ represents the natural logarithm of the share of medium-high and high technology exports, and an export sophistication index, respectively. $\alpha_{i k}$ refers to the unobserved industry and country specific effects and $\varepsilon_{\mathrm{it}} \mathrm{is}$ the error term, $i$ denotes countries, $t$ denotes time, and $k$ denotes industries. Initially, the full set of countries is examined together, to be later split into two sub-groups. The first set of countries refers to selected transition economies ${ }^{14}$ whilst the second represents the European Economic Area $17^{15}$. For comparative purposes, henceforth, these country groups will be referred to as transition (TEs) and non-transition economies (N-TEs). Each model specification is estimated separately for each group. Summary statistics are reported in Table A2 in the appendix.

For the purpose of linearizing and normalizing the distribution of the variables, the ladder of powers approach proposed by Tukey (1977) is employed. The results support the logarithmic transformation of the dependent variables and a number of explanatory variables. No transformation was required or applicable for the remaining set of regressors ${ }^{16}$. In order to assess any potential collinearity between the explanatory variables, the variance inflation factors (VIF) and the correlation matrix have been computed. Both approaches show no major concerns regarding multicollinearity in the dataset. Patent applications and population appear to have higher VIFs compared to other predictors; however, as Wooldridge (2009) argues, if the degree of correlation between control variables does not affect the variables of interest, their partial effects can be determined without difficulties. Collinearity diagnostics are presented in Table A3 in the Appendix.

The fixed effects estimation (FE) is one of the most commonly used methods to estimate longitudinal data, allowing for correlation between the unobserved effect and explanatory variables. However, despite its advantages, the main shortcoming of this approach is the inability to estimate the coefficients of time constant variables. The fixed effects estimation uses a transformation to remove the unobserved specific effect and all the time invariant explanatory variables before estimation (Wooldridge, 2009). This restricts this investigation by omitting one of the main

\footnotetext{
${ }^{14}$ Bulgaria, the Czech Republic, Estonia, Hungary, Lithuania, Latvia, Poland, Romania, the Slovak Republic and Slovenia. Due to the lack of data, Albania, Croatia, Bosnia and Herzegovina, Kosovo, North Macedonia, Montenegro and Serbia are excluded from the regression analysis.

15 Austria, Belgium, Cyprus, Denmark, Finland, France, Germany, Greece, Ireland, Italy, Luxembourg, the Netherlands, Norway, Portugal, Spain, Sweden and the United Kingdom. ${ }^{16}$ Schooling_years, schooling_years^2, cognitive_skills, student_scores, transition_dummy, transition_indicator, unemployment, services_share, and distance.
} 
variables of interest, the quality of education, as well as two controls. To overcome this, alternative estimation methods that share similar features with FE but allow for time-invariant variables in the models have been adopted.

Hausman and Taylor (1981) developed an alternative approach combining features of fixed effects and random effects, by allowing for some explanatory variables to be correlated with unobserved specific effects, while keeping others uncorrelated. The fixed effects vector decomposition, henceforth referred to as FEVD, is another estimator that handles the issue of omitted time invariant variables. FEVD is a three-step procedure that allows for time invariant and rarely changing variables in models estimated with unobserved specific effects. Initially, a model excluding the time invariant regressors is estimated with fixed effects. The second stage involves regressing the unit effects on time invariant and slowly changing regressors. This allows the decomposition of unit effects into explained and unexplained parts. Finally, a pooled OLS model including time varying, time invariant, rarely changing regressors, as well as the unexplained part is estimated. (Plumper and Troeger, 2007; 2011). Given the nature of the data, these two approaches are used to examine the impact of the non-changing variables in this investigation.

A potential source of estimate inconsistency, though largely ignored in previous research, is the presence of endogenous variables in the model due to simultaneity. A feedback effect from exporting technology-intensive goods to education attainment might occur if the increased demand for more educated workers increases the rate of return from investing in additional schooling and hence raises the proportion of the population with higher levels of education. Another feedback effect might occur from exports to innovation. As suggested in the literature, exporters are more likely to engage in innovative activities compared to their counterparts, though the empirical evidence on this relationship is not robust (Salomon and Shaver, 2005; Girma et al., 2008; Van Beveren and Vandenbussche, 2010). The foreign direct investment - exports nexus is also likely to suffer from reverse causation given the assumption that a higher degree of openness, mostly proxied by export engagement, might encourage foreign direct investment. Even though it is unlikely for these relationships to happen simultaneously since it usually takes time for the feedback effects to take place, it is always recommended to be cautious about any form of potential endogeneity and use appropriate estimation methods to account for it. Schaffer's (2010) instrumental variable (IV) estimation approach (xtivreg2) is employed to address the potential endogeneity of education attainment, patent applications and foreign direct investment in this investigation. Given the difficulty of finding suitable instruments, the one period lags of the potential endogenous variables are used as internal instruments in the estimations. 


\section{Results}

\subsection{Export market share}

In line with the theoretical underpinnings, the Fixed Effects IV estimation results indicate that the stock of population with tertiary education plays an important role in determining the technology intensive goods exported by the full sample of countries. On average, it is estimated that an increase of 1 percent in the share of population 15 and over with tertiary education increases the export share of mediumhigh and high technology manufactures by 1.39 percent, ceteris paribus. Similarly, the estimates of model specification 2 show a non-linear relationship between the average years of schooling and the share of technology intensive exports. This quadratic relationship shows that the marginal effect of the years of schooling is negative up to 11.78 , and that it becomes positive afterwards. This result further reinforces the importance of higher levels of education in increasing the share of technology intensive exports. The share of population with secondary education, on the other hand, is not statistically different from zero (Table 1, columns 1 and 4).

The quality of education, proxied by the cognitive skills and student scores indicators, does not appear to exert a significant impact on the share of medium-high and high technology exports (Table 2). A potential explanation for its insignificance might be the lack of variation of these measures within the country. From the set of control variables, the estimated coefficient of total population is found to be negative and highly significant ${ }^{17}$, whereas the hypothesized positive effect of FDI on the share of technology intensive exports is found to be statistically significant only in model specification 2. In line with expectations, the estimated results from the Hausman and Taylor (HT) and Fixed Effect Vector Decomposition (FEVD) estimators suggest a negative relationship between the transition dummy and export market share ${ }^{18}$. The effect of distance is also found to be negative and highly significant across the two estimators (Table 2).

When differentiating between medium-high and high technology exports, the stock of population with tertiary education remains positive and highly significant (Table 1, columns 2 and 3). On average and holding everything else constant, it is estimated that an increase of 1 percent in the share of population with tertiary education increases the share of medium-high technology manufactures exported by these countries by 1.09 percent and the share of high technology exports by 1.69. These findings indicate that the impact of tertiary education is relatively stronger when more technology intensive manufactures are exported. This evidence

\footnotetext{
${ }^{17}$ A potential explanation for this result might be that larger countries rely more on their domestic markets and are less incentivized to engage in international markets through exporting.

${ }^{18}$ With the exception of FEVD Model specification 1.
} 
highlights the relative importance of a highly educated population when more technology intensive goods are to be produced and exported. The marginal effect of the average years of schooling on the share of medium - high technology exports is negative up to 11.21 years and it becomes positive afterwards. When examining the impact of schooling_years on the high technology sample, the marginal effect is negative (10\% significance level) up to 12.27 years, and then it turns insignificant. In line with expectation, the estimated coefficient of the share of population with secondary education is not statistically different from zero.

Table 1. IV Estimation Results for Export Market Share, by Technology Intensity

\begin{tabular}{|c|c|c|c|c|c|c|}
\hline \multirow[b]{2}{*}{$\begin{array}{l}\text { Dependent variable } \\
\text { in log }\end{array}$} & \multicolumn{3}{|c|}{ Model Specification 1} & \multicolumn{3}{|c|}{ Model Specification 2} \\
\hline & $\begin{array}{l}\text { Mid-high } \\
\text { \& high } \\
\text { tech exp }\end{array}$ & $\begin{array}{l}\text { Mid-high } \\
\text { tech exp }\end{array}$ & $\begin{array}{l}\text { High tech } \\
\quad \exp \end{array}$ & $\begin{array}{l}\text { Mid-high } \\
\text { \& high } \\
\text { tech exp }\end{array}$ & $\begin{array}{l}\text { Mid-high } \\
\text { tech exp }\end{array}$ & $\begin{array}{l}\text { High tech } \\
\quad \text { exp }\end{array}$ \\
\hline $\begin{array}{l}\text { Log of } \\
\text { secondary_educ }\end{array}$ & $\begin{array}{l}0.0833 \\
(0.206)\end{array}$ & $\begin{array}{l}-0.216 \\
(0.204)\end{array}$ & $\begin{array}{c}0.383 \\
(0.355)\end{array}$ & & & \\
\hline $\begin{array}{ll}\text { Log } & \text { of } \\
\text { tertiary_educ }\end{array}$ & $\begin{array}{c}1.391 * * * \\
(0.189)\end{array}$ & $\begin{array}{c}1.089 * * * \\
(0.159)\end{array}$ & $\begin{array}{c}1.692 * * * \\
(0.340)\end{array}$ & & & \\
\hline Schooling_years & & & & $\begin{array}{c}-0.968 * * \\
(0.383)\end{array}$ & $\begin{array}{c}-0.852 * * \\
(0.370)\end{array}$ & $\begin{array}{l}-1.085 * \\
(0.658)\end{array}$ \\
\hline Schooling_years^2 & & & & $\begin{array}{c}0.0411^{* *} \\
(0.0175)\end{array}$ & $\begin{array}{c}0.0380^{* *} \\
(0.0167)\end{array}$ & $\begin{array}{c}0.0442 \\
(0.0302)\end{array}$ \\
\hline Log of patents & $\begin{array}{l}-0.0388 \\
(0.0682)\end{array}$ & $\begin{array}{l}0.0961 * \\
(0.0578)\end{array}$ & $\begin{array}{l}-0.174 \\
(0.120)\end{array}$ & $\begin{array}{l}-0.0783 \\
(0.0713)\end{array}$ & $\begin{array}{c}0.0725 \\
(0.0632)\end{array}$ & $\begin{array}{l}-0.229 * \\
(0.124)\end{array}$ \\
\hline Log of FDI & $\begin{array}{l}-0.00505 \\
(0.00967)\end{array}$ & $\begin{array}{c}0.00446 \\
(0.00949)\end{array}$ & $\begin{array}{l}-0.0146 \\
(0.0167)\end{array}$ & $\begin{array}{c}0.0274 * * * \\
(0.00930)\end{array}$ & $\begin{array}{l}0.0304 * * * \\
(0.00882)\end{array}$ & $\begin{array}{c}0.0243 \\
(0.0163)\end{array}$ \\
\hline Log of population & $\begin{array}{c}-7.302 * * * \\
(0.583)\end{array}$ & $\begin{array}{c}-7.905^{* * *} \\
(0.579)\end{array}$ & $\begin{array}{c}-6.700 * * * \\
(0.977)\end{array}$ & $\begin{array}{c}-7.241 * * * \\
(0.572)\end{array}$ & $\begin{array}{c}-7.659 * * * \\
(0.612)\end{array}$ & $\begin{array}{c}-6.823 * * * \\
(0.936)\end{array}$ \\
\hline Unemployment & $\begin{array}{l}-0.000625 \\
(0.00130)\end{array}$ & $\begin{array}{l}-0.00178 \\
(0.00112)\end{array}$ & $\begin{array}{l}0.000533 \\
(0.00233)\end{array}$ & $\begin{array}{l}-0.000924 \\
(0.00130)\end{array}$ & $\begin{array}{l}-0.00204 * \\
(0.00113)\end{array}$ & $\begin{array}{l}0.000196 \\
(0.00231)\end{array}$ \\
\hline $\begin{array}{l}\text { Log of } \\
\text { econ_freedom }\end{array}$ & $\begin{array}{c}0.385 \\
(0.276)\end{array}$ & $\begin{array}{c}0.202 \\
(0.255)\end{array}$ & $\begin{array}{c}0.569 \\
(0.487)\end{array}$ & $\begin{array}{c}0.891 * * * \\
(0.280)\end{array}$ & $\begin{array}{c}0.525^{* *} \\
(0.255)\end{array}$ & $\begin{array}{l}1.258^{* *} \\
(0.495)\end{array}$ \\
\hline Services_share & $\begin{array}{c}0.00618 \\
(0.00822)\end{array}$ & $\begin{array}{l}0.000275 \\
(0.00703)\end{array}$ & $\begin{array}{c}0.0121 \\
(0.0146)\end{array}$ & $\begin{array}{c}0.00824 \\
(0.00840)\end{array}$ & $\begin{array}{c}0.00357 \\
(0.00713)\end{array}$ & $\begin{array}{c}0.0129 \\
(0.0149)\end{array}$ \\
\hline Log of labour_cost & -0.0250 & -0.361 & 0.311 & -0.0972 & -0.375 & 0.181 \\
\hline
\end{tabular}




\begin{tabular}{lcccccc}
\hline & $(0.314)$ & $(0.322)$ & $(0.532)$ & $(0.316)$ & $(0.335)$ & $(0.531)$ \\
No. of observations & 3,450 & 1,725 & 1,725 & 3,450 & 1,725 & 1,725 \\
R-squared & 0.286 & 0.472 & 0.227 & 0.254 & 0.428 & 0.198
\end{tabular}

$\underline{\text { Tests }}$

Kleibergen-Paaprk

$\begin{array}{lcccccc}\text { LM statistic } & 141.704 & 70.852 & 70.852 & 141.896 & 70.948 & 70.948 \\ \text { (p-value) } & (0.000) & (0.000) & (0.000) & (0.000) & (0.000) & (0.000) \\ \text { Kleibergen-Paaprk } & & & & & & \end{array}$

Kleibergen-Paaprk

$\begin{array}{lllllll}\text { Wald F statistic } & 163.187 & 80.999 & 80.999 & 157.036 & 77.946 & 77.946\end{array}$

Notes: Year dummies are included in the estimations but are not reported in the table.

$* * * \mathrm{p}<0.01, * * \mathrm{p}<0.05, * \mathrm{p}<0.1$; Heteroskedasticity and autocorrelation robust standard errors are reported in parentheses. The HAC standard errors were obtained through the Bartlett (Newey and West) kernel option ${ }^{19}$.

Secondary_educ, tertiary_educ, schooling_years, schooling_years ${ }^{\wedge} 2$, patents, and FDI are treated as endogenous. One period lagged values of these variables are used as internal instruments in the estimations. To assess the quality of these instruments, two tests have been conducted. The Kleibergen-Paaprk LM statistic represents an underidentification test which assesses whether the instruments are correlated with the endogenous variables. The Kleibergen-Paaprk Wald F test shows if this correlation is weak. Both statistics suggest that the estimated models are not underidentified, and that the instruments are not weakly correlated with the endogenous variables.

Source: Author's calculations

Table 2. HT and FEVD Estimation Results for Export Market Share

\begin{tabular}{lccccc}
\hline & \multicolumn{2}{c}{ Model Specification 1 } & & \multicolumn{2}{c}{ Model Specification 2 } \\
\cline { 2 - 3 } \cline { 5 - 6 } $\begin{array}{l}\text { Dependent variable } \\
\text { in log }\end{array}$ & $\begin{array}{c}\text { Mid-high \& } \\
\text { high tech exp }\end{array}$ & $\begin{array}{c}\text { Mid-high \& } \\
\text { high tech exp }\end{array}$ & & $\begin{array}{c}\text { Mid-high \& } \\
\text { high tech exp }\end{array}$ & $\begin{array}{c}\text { Mid-high \& } \\
\text { high tech exp }\end{array}$ \\
\hline \multirow{2}{*}{ Cognitive_skills } & -0.232 & -1.880 & & 1.033 & -0.644 \\
& $(4.530)$ & $(6.043)$ & & $(4.349)$ & $(4.345)$ \\
Student_scores & -0.00383 & -0.0515 & & 0.00424 & -0.0405 \\
& $(0.0391)$ & $(0.0515)$ & & $(0.0378)$ & $(0.0353)$ \\
Distance & $-0.00395 * * *$ & $-0.00474 * * *$ & & $-0.00384 * * *$ & $-0.00466 * * *$ \\
& $(0.00127)$ & $(0.00159)$ & & $(0.00122)$ & $(0.00150)$ \\
Transition_dummy & $-2.903 * *$ & -4.875 & & $-2.910 * *$ & $-4.890 * *$ \\
& $(1.372)$ & $(3.154)$ & & $(1.318)$ & $(2.387)$ \\
\hline
\end{tabular}

${ }^{19}$ In an alternative approach, clusters by country/industry were used; however, due to restricted number of clusters, especially for the sub-country and sub-industry analyses, those results are not reported. 


\begin{abstract}
No. of observations
3,600

3,600

3,600

3,600

Notes: Control variables and year dummies are included in the estimations but are not reported in the table. $* * * \mathrm{p}<0.01, * * \mathrm{p}<0.05, * \mathrm{p}<0.1$; Standard errors in parentheses;

To avoid collinearity, Cognitive_skills and Student_scores are included in alternative model specifications.
\end{abstract}

Source: Author's calculations

To examine if there are differences between transition (TEs) and nontransition (N-TEs) countries, two pairs of estimations have been conducted. Initially, Chow tests were used to check the equality of the effects of the explanatory variables for both sets of countries. The null hypothesis of equal coefficients has been rejected in both model specifications with $\mathrm{F}_{9,3148}$ statistics of 13.30 (p-value: 0.000 ) and 20.61 (p-value: 0.000 ), respectively ${ }^{20}$. Country group results are reported in Table 3 . Based on the IV estimates, the stock of population with tertiary education does not appear to have any explanatory power in the TEs sample. This result might be attributed to these countries' less sophisticated export baskets, and/or potential skill and qualification mismatches. The indicator representing these mismatches, long term unemployment, as expected, is found to exert a negative impact on the share of technology intensive exports of TEs.

Table 3. IV Estimation Results for Export Market Share, by Country Group

\begin{tabular}{|c|c|c|c|c|}
\hline & \multicolumn{2}{|c|}{ Model Specification 1} & \multicolumn{2}{|c|}{ Model Specification 2} \\
\hline & TE-s & N-TES & TE-s & N-TEs \\
\hline $\begin{array}{l}\text { Dependent variable in } \\
\log \end{array}$ & $\begin{array}{l}\text { Mid-high \& } \\
\text { high tech } \\
\text { exp }\end{array}$ & $\begin{array}{l}\text { Mid-high \& } \\
\text { high tech } \\
\text { exp }\end{array}$ & $\begin{array}{l}\text { Mid-high \& } \\
\text { high tech } \\
\text { exp }\end{array}$ & $\begin{array}{l}\text { Mid-high \& } \\
\text { high tech } \\
\text { exp }\end{array}$ \\
\hline Log of secondary_educ & $\begin{array}{l}-0.0675 \\
(0.744)\end{array}$ & $\begin{array}{c}-0.312 * * \\
(0.158)\end{array}$ & & \\
\hline Log of tertiary_educ & $\begin{array}{c}-0.792 \\
(0.503)\end{array}$ & $\begin{array}{c}0.261 \\
(0.236)\end{array}$ & & \\
\hline Schooling_years & & & $\begin{array}{c}0.546 \\
(1.238)\end{array}$ & $\begin{array}{c}0.148 \\
(0.323)\end{array}$ \\
\hline Schooling_years ${ }^{\wedge} 2$ & & & $\begin{array}{c}-0.0317 \\
(0.0526)\end{array}$ & $\begin{array}{c}-0.0104 \\
(0.0147)\end{array}$ \\
\hline Log of patents & $\begin{array}{c}-0.554 * * * \\
(0.214)\end{array}$ & $\begin{array}{l}0.139 * * \\
(0.0645)\end{array}$ & $\begin{array}{c}-0.531 * * \\
(0.220)\end{array}$ & $\begin{array}{c}0.0720 \\
(0.0650)\end{array}$ \\
\hline Log of FDI & -0.117 & 0.0114 & -0.0606 & 0.0146 \\
\hline
\end{tabular}

${ }^{20}$ Models were estimated on the full set of countries including the explanatory variables and their interactions with the transition dummy. The joint significance of the interaction terms was tested by an F-test. 


\begin{tabular}{lcccc}
\hline & $(0.166)$ & $(0.00938)$ & $(0.150)$ & $(0.00946)$ \\
Log of population & 0.483 & $-2.685^{* * *}$ & -0.378 & $-1.728^{* * *}$ \\
Unemployment & $(2.959)$ & $(0.613)$ & $(4.187)$ & $(0.535)$ \\
& $-0.0103^{* * *}$ & 0.000231 & $-0.00991^{* * *}$ & 0.000584 \\
Log of econ_freedom & $(0.00252)$ & $(0.00124)$ & $(0.00271)$ & $(0.00127)$ \\
& 0.320 & -0.118 & 0.276 & -0.135 \\
Services_share & $(0.514)$ & $(0.270)$ & $(0.500)$ & $(0.266)$ \\
& -0.00914 & $-0.0135^{*}$ & -0.0141 & $-0.0120^{*}$ \\
Log of labour cost & $(0.0156)$ & $(0.00706)$ & $(0.0155)$ & $(0.00707)$ \\
& 0.634 & $-0.749^{*}$ & $0.773^{*}$ & $-0.716^{*}$ \\
Trans_indicator & $(0.462)$ & $(0.400)$ & $(0.463)$ & $(0.393)$ \\
& -0.422 & & -0.612 & \\
No. of observations & $(0.843)$ & & $(0.867)$ & \\
R-squared & 1,339 & 2,120 & 1,330 & 2,120 \\
& 0.435 & 0.099 & 0.437 & 0.104 \\
Tests & & & & \\
Kleibergen-Paaprk LM & & & & \\
statistic & 116.044 & 108.764 & 124.121 & 101.303 \\
(p. value) & $(0.000)$ & $(0.000)$ & $(0.000)$ & $(0.000)$ \\
Kleibergen-Paaprk & & & & \\
Wald F statistic & 121.651 & 78.703 & 74.943 & 66.306 \\
\hline
\end{tabular}

Notes: Year dummies are included in the estimations but are not reported in the table. $* * * p<0.01, * * p<0.05, * p<0.1$; Heteroskedasticity and autocorrelation robust standard errors are reported in parentheses. The HAC standard errors were obtained through the Bartlett (Newey and West) kernel option ${ }^{21}$.

Secondary_educ, tertiary_educ, schooling_years, schooling_years ${ }^{\wedge}$, patents, and FDI are treated as endogenous. One period lagged values of these variables are used as internal instruments in the estimations. To assess the quality of these instruments, two tests have been conducted. The Kleibergen-Paaprk LM statistic represents an underidentification test which assesses whether the instruments are correlated with the endogenous variables. The Kleibergen-Paaprk Wald F test shows if this correlation is weak. Both statistics suggest that the estimated models are not underidentified, and that the instruments are not weakly correlated with the endogenous variables.

Source: Author's calculations

When N-TEs are assessed separately, their share of population with secondary education was found to exert a negative impact on the share of technology intensive exports. Given the more sophisticated export composition of these countries, the relative size of the secondary educated workforce is not expected to contribute to

${ }^{21}$ In an alternative approach, clusters by country/industry were used; however, due to the restricted number of clusters, especially for the sub-country and sub-industry analyses, those results are not reported. 
their productivity and competitiveness. The share of population with tertiary education, as well as the average years of schooling (level and squared) are statistically insignificant. The coefficient of patent applications is significant in both samples of countries, but with different signs, i.e. negative for TEs and positive for N-TEs whereas population, unit labour cost, and the share of services appear to have a negative impact on the export share of N-TE only.

The results of the time-invariant predictors produced by the Hausman and Taylor (HT) and Fixed Effects Vector Decomposition (FEVD) estimators support the anticipated positive relationship between the quality of education and the share of technology intensity exports in most of the country group specifications (Tables $4 \& 5$ ). According to the FEVD estimated results, the quality of education, proxied by the cognitive skills index is positive and statistically significant in both country groups, the magnitude of the coefficients being larger in the TEs. The alternative measure of quality, student test scores is significant only in the non-transition set of countries (Model Specification 1). The HT estimator, on the other hand, shows a positive association between the student test scores and the export share of mediumhigh and high tech goods in both samples of countries (10\% significance level). The coefficient of the cognitive skills produced by the HT estimator is positive and significant only in the sample of non-transition countries (N-TEs).

Table 4. HT Estimation Results for Export Market Share, by Country Group

\begin{tabular}{|c|c|c|c|c|}
\hline & \multicolumn{4}{|c|}{ HT } \\
\hline & \multicolumn{2}{|c|}{ Model Specification 1} & \multicolumn{2}{|c|}{ Model Specification 2} \\
\hline & TEs & N-TEs & TEs & N-TEs \\
\hline $\begin{array}{l}\text { Dependent } \\
\text { variable in log }\end{array}$ & $\begin{array}{c}\text { Mid-high \& } \\
\text { high tech exp }\end{array}$ & $\begin{array}{c}\text { Mid-high \& } \\
\text { high tech exp }\end{array}$ & $\begin{array}{c}\text { Mid-high \& } \\
\text { high tech exp }\end{array}$ & $\begin{array}{c}\text { Mid-high \& } \\
\text { high tech exp }\end{array}$ \\
\hline Cognitive_skills & $\begin{array}{c}2.644 \\
(1.668)\end{array}$ & $\begin{array}{c}3.461 * * \\
(1.700)\end{array}$ & $\begin{array}{c}2.469 \\
(1.842)\end{array}$ & $\begin{array}{c}3.195^{* *} \\
(1.431)\end{array}$ \\
\hline Students_scores & $\begin{array}{l}0.0222^{*} \\
(0.0128)\end{array}$ & $\begin{array}{l}0.0301^{*} \\
(0.0169)\end{array}$ & $\begin{array}{l}0.0185^{*} \\
(0.0101)\end{array}$ & $\begin{array}{l}0.0269^{*} \\
(0.0142)\end{array}$ \\
\hline Distance & $\begin{array}{c}-0.00176^{* *} \\
(0.000819)\end{array}$ & $\begin{array}{c}-0.00115^{* * * *} \\
(0.000429)\end{array}$ & $\begin{array}{c}-0.00220 * * \\
(0.000901)\end{array}$ & $\begin{array}{c}-0.00112 * * * \\
(0.000360)\end{array}$ \\
\hline $\begin{array}{l}\text { No. } \\
\text { observations }\end{array}$ & 1,370 & 2,230 & 1,370 & 2,230 \\
\hline
\end{tabular}

Notes: Control variables and year dummies are included in the estimations but are not reported in the table.

$* * * \mathrm{p}<0.01,{ }^{*} \mathrm{p}<0.05,{ }^{*} \mathrm{p}<0.1$; Standard errors in parentheses;

To avoid collinearity, Cognitive_skills and Student_scores are included in alternative model specifications.

Source: Author's calculations 
Table 5. FEVD Estimation Results for Export Market Share, by Country Group

\begin{tabular}{|c|c|c|c|c|}
\hline & \multicolumn{4}{|c|}{ FEVD } \\
\hline & \multicolumn{2}{|c|}{ Model Specification 1} & \multicolumn{2}{|c|}{ Model Specification 2} \\
\hline & TEs & N-TEs & TEs & N-TEs \\
\hline $\begin{array}{l}\text { Dependent } \\
\text { variable in log }\end{array}$ & $\begin{array}{c}\text { Mid-high \& } \\
\text { high tech exp }\end{array}$ & $\begin{array}{c}\text { Mid-high \& } \\
\text { high tech exp }\end{array}$ & $\begin{array}{c}\text { Mid-high \& } \\
\text { high tech exp }\end{array}$ & $\begin{array}{r}\text { Mid-high \& } \\
\text { high tech exp }\end{array}$ \\
\hline Cognitive_skills & $\begin{array}{c}10.22 * * * \\
(2.742)\end{array}$ & $\begin{array}{c}6.447 * * * \\
(2.479)\end{array}$ & $\begin{array}{c}11.08 * * * \\
(2.912)\end{array}$ & $\begin{array}{c}5.830 * * * \\
(2.075)\end{array}$ \\
\hline Students_scores & $\begin{array}{l}0.0762 \\
(0.201)\end{array}$ & $\begin{array}{c}0.0454 * * \\
(0.0212)\end{array}$ & $\begin{array}{c}0.0488 \\
(0.0542)\end{array}$ & $\begin{array}{c}0.0420 \\
(0.0526)\end{array}$ \\
\hline Distance & $\begin{array}{l}0.000812 \\
(0.00120)\end{array}$ & $\begin{array}{l}-0.00156 \\
(0.00268)\end{array}$ & $\begin{array}{l}0.000751 \\
(0.00117)\end{array}$ & $\begin{array}{c}-0.00144 * * \\
(0.000570)\end{array}$ \\
\hline $\begin{array}{l}\text { No. of } \\
\text { observations }\end{array}$ & 1,370 & 2,230 & 1,370 & 2,230 \\
\hline
\end{tabular}

Notes: Control variables and year dummies are included in the estimations but are not reported in the table.

$* * * \mathrm{p}<0.01, * * \mathrm{p}<0.05,{ }^{*} \mathrm{p}<0.1$; Standard errors in parentheses;

To avoid collinearity, Cognitive_skills and Student_scores are included in alternative model specifications.

Source: Author's calculations

The hypothesized importance of the quality of education is further tested in an additional regression analysis, using a slightly smaller dataset, including a time varying quality proxy. This measure, representing secondary education students' performance provided by Altinok et al. (2014), exerts a positive impact on the NTEs sample only. Holding everything else constant, an increase of 1 percent in the mean value of these students' test scores increases the share of medium-high and high technology exports by 2.24 percent. When interpreted at the mean values of the measures, an increase of 10 percent in student_performance (i.e. from 566.34 to 622.97) increases the share of medium and high technology exports from 7.34 to 8.98. The full set of results from this regression analysis is presented in Table A4, in the appendix.

\subsection{Export Sophistication}

The estimation results based on the full sample of countries show that, in line with expectations, a higher share of population with tertiary education has a positive and highly significant impact on export sophistication. (Table 6, column 1). An increase of 1 percent in tertiary_educ, holding everything else unchanged, increases export sophistication index by 0.38 percent. From the set of controls, population is 
found to exert a robust negative impact in both model specifications while the coefficient of foreign direct investment is statistically different from zero only in model specification 2 .

When transition (TEs) and non-transition economies (N-TEs) are estimated separately, the tertiary education indicator remains statistically significant only in the N-TEs sample. Holding other factors constant, an increase of 1 percent in the stock of population who have attained tertiary education increases the export sophistication index by 0.24 percent (10\% significance level). This supports the hypothesis that investing in higher levels of education plays an important role in enhancing the export sophistication of non-transition countries. The insignificance of the coefficients of the average years of schooling and the non-changing measures of the quality of education is persistent across the two samples of countries (Table 7). The statistical significance of control variables appears to diverge across country groups: the coefficient of long term unemployment rate is statistically significant in the TEs sample while the share of inward FDI, total population, and the share of services appear to have a significant impact on exports sophistication, only for $\mathrm{N}$ TEs (Table 6).

The results from the HT and FEVD estimators do not suggest any supporting evidence for the hypothesized link between the time-invariant measure of the quality of education (cognitive_skills and student_scores) and export sophistication in either country group ${ }^{22}$. When the quality of education is proxied by a time changing indicator, in an alternative regression analysis, the results support the positive effect of student_performance on export sophistication of N-TEs. On average, an increase of 1 percent in the student test performance increases export sophistication by 1.64 percent, ceteris paribus. For illustration, at the sample means, an increase of 10 percent in student_performance (from 565.77 to 622.35) is estimated to increase export sophistication of non-transition economies from 12,538 to 14,594. In line with expectations, this finding highlights the importance of higher quality education for countries that are engaged in exporting more sophisticated goods. The full set of results from this analysis is reported in Table A5, in the appendix.

\section{Table 6. IV Estimation Results for Export Sophistication}

\begin{tabular}{lcccccc}
\hline & \multicolumn{3}{c}{ Model Specification 1 } & \multicolumn{3}{c}{ Model Specification 2 } \\
\cline { 2 - 7 } & $\begin{array}{c}\text { Full } \\
\text { sample }\end{array}$ & TEs & N-TEs & $\begin{array}{c}\text { Full } \\
\text { sample }\end{array}$ & TEs & N-TEs \\
\hline $\begin{array}{l}\text { Dependent } \\
\text { variable in log }\end{array}$ & Exp_soph & Exp_soph & Exp_soph & Exp_soph & Exp_soph & Exp_sophi \\
\hline & & & & & & \\
Log of & -0.201 & -0.555 & -0.152 & & & \\
secondary_educ & $(0.169)$ & $(0.577)$ & $(0.118)$ & & & \\
\hline
\end{tabular}

${ }^{22}$ The full set of results from this regression analysis is available on request. 


$\begin{array}{lcccc}\log & \text { of } & 0.368^{* * *} & -0.316 & 0.243^{*} \\ \text { tertiary_educ } & & (0.132) & (0.407) & (0.143)\end{array}$

Schooling_years

Schooling_years^2

Log of patents

0.00802

$-0.237$

$-0.198$

-0.198
$(0.275)$

1.060

0.249

0.00690

(1.074)

(0.196)

$(0.0123)$

$-0.0502$

$-0.0129$

(0.0473)

(0.161)

0.0822

$-0.00694$

(0.0436)

(0.00923)

Log of FDI

0.00749

0.0136

(0.0519)

(0.0504)

$-0.0853$

0.0343

(0.00506)

(0.103)

$0.0123 * *$

$0.0162 * * *$

(0.177)

(0.0547)

Log of population

$-1.865^{* * *}$

(0.00492)

(0.00416)

0.0175

$0.0138 * * *$

(0.431)

$-0.0710$

$-1.521 * * *$

$-1.696^{* * *}$

(0.0840)

(0.00441)

Unemployment

$-0.00118$

(2.281)

(0.457)

(0.476)

2.667

$-0.895^{* *}$

$-0.000262-0.00122$

(3.036)

(0.440)

$0.00606 * *$

$\begin{array}{ll}(0.000982) & (0.00234)\end{array}$

(0.000790)

(0.00105)

$0.00565 * *$

5.47e-05

Log of

0.207

0.0871

0.327

0.334

(0.00250)

(0.000815)

econ_freedom

(0.254)

(0.453)

(0.227)

(0.233)

$-0.143$

0.300

Services_share

$0.00815 \quad-0.0126$

$0.0150 * *$

0.00904

(0.453)

(0.234)

Log of labour cost

(0.00554)

(0.0129)

(0.00725)

(0.00562)

$-0.00892$

$0.0147 * *$

0.219

0.347

0.107

0.263

(0.0115)

(0.00703)

(0.325)

(0.381)

(0.324)

(0.339)

0.269

0.172

Trans_indicator

$-0.726$

(0.617)

(0.354)

(0.325)

No. of 349

134

215

349

$-0.653$

(0.593)

observations

R-squared

0.632

0.708

0.658

0.600

134

215

Tests

Kleibergen-Paaprk

LM statistic

(p. value)

Kleibergen-Paaprk

$\begin{array}{lllllc}14.393 & 12.264 & 10.610 & 14.028 & 13.020 & 9.943 \\ (0.000) & (0.000) & (0.001) & (0.000) & (0.000) & (0.001)\end{array}$

Wald F statistic

$15.643 \quad 11.027$

6.843

14.872

6.540

5.915

\begin{abstract}
Notes: Year dummies are included in the estimations but are not reported in the table.
$* * * \mathrm{p}<0.01, * * \mathrm{p}<0.05, * \mathrm{p}<0.1$; Heteroskedasticity and autocorrelation robust standard errors are reported in parentheses. The HAC standard errors were obtained through the Bartlett (Newey and West) kernel option ${ }^{23}$.
\end{abstract}

\footnotetext{
${ }^{23}$ In an alternative approach, clusters by country/industry were used; however, due to the restricted number of clusters, especially for the sub-country and sub-industry analyses, those results are not reported.
} 
Secondary_educ, tertiary_educ, schooling_years, schooling_years ${ }^{\wedge} 2$, patents, and FDI are treated as endogenous. One period lagged values of these variables are used as internal instruments in the estimations. To assess the quality of the instruments, two tests have been conducted. The Kleibergen-Paaprk LM statistic represents an underidentification test which assesses whether instruments are correlated with the endogenous variables. The KleibergenPaaprk Wald F test shows if this correlation is weak. The results of these tests suggest that the estimated models are not underidentified; however, there might be a potential weak correlation problem in the country group samples (F statistic $<10)$.

Source: Author's calculations

Table 7. HT and FEVD Estimation Resultsfor Export Sophistication

\begin{tabular}{lcccc}
\hline & \multicolumn{2}{c}{ Model Specification 1 } & \multicolumn{2}{c}{ Model Specification 2 } \\
\cline { 2 - 5 } & HT & FEVD & HT & FEVD \\
\hline $\begin{array}{l}\text { Dependent variable } \\
\text { in log }\end{array}$ & Exp_soph & Exp_soph & Exp_soph & Exp_soph \\
\hline \multirow{2}{*}{ Cognitive_skills } & -0.0807 & 0.573 & 0.310 & 0.908 \\
& $(3.273)$ & $(7.048)$ & $(2.791)$ & $(2.496)$ \\
Student_scores & -0.00471 & -0.00949 & -0.00168 & -0.00486 \\
& $(0.0281)$ & $(0.0419)$ & $(0.0241)$ & $(0.0208)$ \\
Distance & $(0.0281)$ & -0.000672 & -0.000538 & -0.000587 \\
& $(0.000915)$ & $(0.00119)$ & $(0.000781)$ & $(0.000960)$ \\
Transition_dummy & -0.343 & -0.740 & -0.311 & -0.701 \\
& $(0.992)$ & $(4.395)$ & $(0.847)$ & $(1.920)$ \\
No. & 366 & 366 & 366 & 366 \\
Observations & & & & \\
\hline
\end{tabular}

Notes: Control variables and year dummies are included in the estimations but are not reported in the table.

$* * * \mathrm{p}<0.01, * * \mathrm{p}<0.05, * \mathrm{p}<0.1$; Standard errors in parentheses;

To avoid collinearity, Cognitive_skills and Student_scores are included in alternative model specifications.

Source: Author's calculations

\section{Conclusions}

Even though considerable research has been dedicated to the construction of indices to measure international competitiveness, the determinants of their variation across countries and time have not been fully investigated. Hence, to fill this void, the impact of education on the international competitiveness of 27 European countries, with special focus on technology intensive exports, has been assessed. To draw a clearer and more conclusive inference, the empirical investigation made use of a comprehensive set of measures of education and international competitiveness. 
The recent research on human capital accumulation has highlighted the importance of focusing on the quality as well as on the quantity of education; hence, a measure of the former dimension was also integrated into the regression analysis. To assess the robustness of the empirical results and also, to account for time invariant and potentially endogenous variables, a diversified modelling strategy was employed.

The full sample results suggest that the stock of population with tertiary education exerts a positive and significant impact on the share of medium-high and high technology exports, the impact being relatively stronger for the high technology category. The importance of higher levels of education was also supported by the increasing effect of the average years of schooling on the share of technology intensive exports. When transition economies (TEs) are assessed separately, the tertiary education indicator becomes statistically insignificant. This result may be attributed to skill mismatch issues prevailing in the region as well as to their less technology intensive exports. In line with the theoretical framework outlined in this paper, a higher level of education attainment is more likely to enhance the productivity of workers when more advanced activities are to be performed. The estimation results from the N-TEs sample suggest a negative association between the stock of population with secondary education and the technology intensive export share. The hypothesized importance of the quality of education is tested in several model specifications for both sets of countries, separately, and the overall evidence, in line with expectations, is positive and significant.

The empirical findings also support a positive and highly significant link between the stock of population with tertiary education and the export sophistication of the full set of countries. When transition (TEs) and non-transition economies (TEs) are assessed separately, the tertiary education indicator remains statistically significant only in the non-transition set of countries. This particular result might be attributed to the more sophisticated composition of exports in these countries compared to their transition counterparts. With regard to the quality of education, the evidence from the export sophistication analysis is more restricted. The time invariant measures of cognitive skills and student test score did not seem to have any explanatory power in either of the model specifications or samples, whereas the alternative, time varying proxy exerted a positive impact on the export sophistication of N-TEs only.

Given the importance of specializing in high skill and technology intensive goods for economic growth, public policies in these countries should redirect their focus towards high profile skilled individuals. The positive impact of the stock of population with tertiary education on the share of technology intensive goods exported by EU-27 and their export sophistication emphasize the relative importance of higher levels of education for these sectors and, in turn, suggests specific policy interventions. Policy makers are advised to place more emphasis on promoting higher education attainment in subjects relevant to their profile of exports, particularly if these countries aim at maintaining and enhancing their competitive 
positions in more technology intensive goods. Potential interventions might involve expanding the expenditure on more technology-related study programmes rather than on generic ones.

This finding might also have implications for attracting highly-qualified employees from other countries or, in the context of transition economies, for attracting back students and emigrants who have undertaken higher education abroad. International emigration rates are relatively high in many transition economies, with a substantial number of the emigrants being highly-skilled workers (EBRD, 2013; Arias et al., 2014). Hence, to prevent the loss of actual and potential highly-qualified workers, policy makers in these countries should place more focus on creating the economic conditions that help retain or bring this group back. Transition countries should therefore continue the process of reforming their public sectors and labour markets; foster employment through promoting entrepreneurship as a key source of job creation; designing adequate integration programmes for migrants to assist and facilitate their incorporation into labour markets; and improve the business climate to encourage returning emigrants to invest.

The absence of supporting evidence for the role of education attainment of the population on the sample of TEs makes it more difficult to make any suggestions on potential policy actions. It has been argued above that this lack of evidence might be due to their generally less sophisticated export baskets; hence, policy interventions that encourage these countries to switch to producing and exporting more sophisticated goods are recommended. Potential policy actions involve encouraging entrepreneurs to engage in more skilled and technology based goods via subsidizing their investments in these activities, supporting technological transfer and accumulation and attracting foreign direct investment. Even though the structure of exports in many transition countries has changed significantly in recent years, greater investment in human capital accumulation might still be warranted to help them catch-up with their non-transition counterparts.

Acknowledgement: The author thanks the anonymous reviewers for their helpful comments and suggestions.

\section{References}

Altinok, N., Diebolt, C. and De Meulemeester, J. (2014), A new international database on education quality: 1965-2010, Applied Economics, 46(11), pp. 1212-1247. https://doi.org/10.1080/00036846.2013.868592

Anand, R., Mishra, S. and Spatafora, N. (2012), Structural Transformation and the Sophistication of Production, International Monetary Fund Working Papers No. $12 / 59$. 
Arias, O., Sánchez-Páramo, C., Dávalos, M., Santos, I., Tiongson, E., Gruen, C., de Andrade Falcão, N., Saiovici, G. and Cancho, C. (2014), Back to Work: Growing with Jobs in Europe and Central Asia, Washington, DC: World Bank.

Barro, R. and Lee, J. (2014), Educational Attainment Dataset, Version 2.0.

Becker, G. (1964), Human Capital, New York: Columbia University Press.

Behar, A. and Venables, A. (2010), Transport costs and international trade, University of Oxford, Department of Economics Discussion Paper Series, No. 488.

Cabral, M. and Veiga, P. (2010), Determinants of Export Diversification and Sophistication in Sub-Saharan Africa, Universidade Nova de Lisboa, Faculdade de Economia, Working Paper, No. wp550.

Cavallaro, E., Esposito, P., Matano, A. and Mulino, M. (2012), Technological catching up, quality of exports and competitiveness: a sectoral perspective, University of Rome La Sapienza, Department of Public Economics, Working Paper, No. 158.

Corvers, F. and Grip, A. (1997), Explaining trade in industrialized countries by countryspecific human capital endowments, Economic Modelling, 14(3), pp. 395-416.

EBRD (2013), Transition report 2013. Stuck in Transition?, London: European Bank for Reconstruction and Development.

EBRD (2014), Transition indicators database, London: European Bank for Reconstruction and Development.

European Commission (2011), Innovation Union Scoreboard 2011, Research and Innovation Union scoreboard, Brussels: Directorate General for Enterprise and Industry.

Ferragina, A. and Pastore, F. (2007), High tech export performance: which role for diversification?, Ninth Annual Conference 13-15 September, Athens University of Economics and Business.

Girma, S., Görg, H. and Hanley, A. (2008), R\&D and exporting: A comparison of British and Irish firms, Review of World Economics, 144(4), pp. 750-773.

Gökmen, Y. and Turen, U. (2013), The Determinants of High Technology Exports Volume: A Panel Data Analysis of EU-15 Countries, International Journal of Management, Economics and Social Sciences, 2(3), pp. 217 -232.

Güneş, S., Gürel, S.P., Karadam, D.Y. and Akin, T. (2020), The analysis of main determinants of high technology exports: A panel data analysis, KAUJEASF, 11(21), pp. 242- 267.

Hanushek, E. and Woessmann, L. (2012), Do Better Schools Lead to More Growth? Cognitive Skills, Economic Outcomes, and Causation, Journal of Economic Growth, 17(4), pp. 267-321. https://doi.org/10.1007/s10887-012-9081-x

Hausman, J. and Taylor, W. (1981), Panel data and unobservable individual effects, Econometrica, 49(6), pp. 1377-1398.

Hausmann, R., Hwang, J. and Rodrik, D. (2007), What You Export Matters, Journal of Economic Growth, 12(1), pp. 1-25. https://doi.org/10.1007/s10887-006-9009-4 
Huseyni, I. and Cakmak, E. (2019), Determinants of Export Sophistication: An Investigation for Selected Developed and Developing Countries Using Second-Generation Panel Data Analyses, EkonomickyCasopis, 67(5), pp. 481-503.

Jarreau, J. and Poncet, J. (2009), Sophistication of China's exports and foreign spillovers, The Centre d'EtudesProspectives et d'InformationsInternationales (CEPII), Working Paper No. 0917.

Jarreau, J. and Poncet, S. (2012), Export sophistication and economic growth: Evidence from China, Journal of Development Economics, 97(2012), pp. 281-292. https://doi.org/10.1016/j.jdeveco.2011.04.001

Kočenda, E. and Poghosyan, K. (2018), Export Sophistication: A Dynamic Panel Data Approach, Emerging Markets Finance \& Trade, 54(12), pp. 2799-2814. https://doi.org/10.1080/1540496X.2017.1412305

Lucas, R. (1988), On the mechanics of economic development, Journal of Monetary Economics, 22(1), pp. 3-42.

Mulliqi, A., Adnett, N., Hisarciklilar, M. and Rizvanolli, A. (2018), Human Capital and International Competitiveness in Europe, with Special Reference to Transition Economies, Eastern European Economics, 56(6), pp. 541-563. https://doi.org/10.1080/00128775.2018.1502612

Nelson, R. and Phelps, E. (1966), Investment in humans, technological diffusion, and economic growth, American Economic Review, 56(1/2), pp. 69-75.

OECD (2002), Measuring the Non-Observed Economy: A Handbook, Paris: OECD.

OECD (2013), STAN Bilateral Trade Database by Industry and End-use category (BTDIxE), edition 2012, ISIC revision 3, Paris: OECD.

Plumper, T. and Troeger, V. (2007), Efficient estimation of time-invariant and rarely changing variables in finite sample panel analyses with unit fixed effects, Political Analysis, 15, pp. 124-139. https://doi.org/10.1093/pan/mpm002

Plumper, T. and Troeger, V. (2011), Fixed-Effects Vector Decomposition: Properties, Reliability, and Instruments, Political Analysis, 19, pp. 147-164. https://doi.org/10.1093/pan/mpr008

Rodrik, D. (2006), What's so special about China's Exports?, NBER Working Paper, No. 11947.

Romer, P. (1990), Endogenous technological change, Journal of Political Economy, 98(5), pp. S71-S102.

Rosenzweig, M. (1995), Why Are There Returns to Schooling?, American Economic Review, 85(2), pp. 153-158.

Rosenzweig, M. (1996), When Investing in Education Matters and When It Does Not, Challenge, 39(2), pp. 22-29.

Salomon, R.M. and Shaver, J.M. (2005), Learning by exporting: new insights from examining firm innovation, Journal of Economics \& Management Strategy, 14(2), pp. 431-460. https://doi.org/10.1111/j.1530-9134.2005.00047.x 
Schaffer, M. (2010), xtivreg2: Stata module to perform extended IV/2SLS, GMM and AC/HAC, LIML and $k$-class regression for panel data models (retrieved from http://ideas.repec.org/c/boc/bocode/s456501.html).

Srholec, M. (2007), High-tech exports from developing countries: A symptom of technology spurts or statistical illusion?, Review of World Economics/WeltwirtschaftlichesArchiv, 143(2), pp. 227-255.

Tebaldi, E. (2011), The Determinants of High-Technology Exports: A Panel Data Analysis, Atlantic Economic Journal, 39(4), pp 343-353. https://doi.org/10.1007/s11293-011$\underline{9288-9}$

Tukey, J. (1977), Exploratory Data Analysis, Reading, MA: Addison-Wesley.

UNCTAD (2014), Merchandise trade matrix database: detailed products, exports in thousands of dollars, annual, 1995-2013, SITC revision 3, New York: United Nations.

Van Beveren, I. and Vandenbussche, H. (2010), Product and process innovation and firms' decision to export, Journal of Economic Policy Reform, 13(1), pp. 3-24. https://doi.org/10.1080/17487870903546267

Vogiatzoglou, K. (2009), Determinants of Export Specialization in ICT Products: A CrossCountry Analysis, International Network for Economic Research, Working Papers No. 2009.3.

Wang, Z. and Wei, S. (2008), What Accounts for the Rising Sophistication of China's Exports?, NBER Working Paper No. 13771.

Weldemicael, E. (2012), Determinants of Export Sophistication, The University of Melbourne.

Wooldridge, J. (2009), Introductory Econometrics, Fourth Edition, Mason: South Western Cengage Learning.

Zhu, Sh., Fu, X., Lai, M. and Xuan, J. (2009), What Drives the Export Sophistication of Countries?, University of Oxford, Department of International Development. SLPTMD Working Paper Series No. 


\section{Appendix}

\section{Table A1. Variable descriptions}

\begin{tabular}{|c|c|c|c|}
\hline Variable name & Description & $\begin{array}{l}\text { Expected } \\
\text { sign }\end{array}$ & Data source \\
\hline $\begin{array}{l}\text { Mid-high \& } \\
\text { high tech exp }\end{array}$ & $\begin{array}{l}\text { The share of a country's exports in } \\
\text { medium-high and high tech } \\
\text { industries in the exports of the } \\
\text { same industries in EU-28 (in } \\
\text { percentages) }\end{array}$ & $\begin{array}{c}\text { Dep. } \\
\text { variable }\end{array}$ & $\begin{array}{l}\text { Own calculations based } \\
\text { OECD STAN Bilateral } \\
\text { Trade Database by Industry } \\
\text { and End-use category, based } \\
\text { on } 2 \text { digit level, ISIC } \\
\text { revision } 3 \text { (OECD, 2013) }\end{array}$ \\
\hline $\begin{array}{l}\text { Mid-high tech } \\
\text { exp }\end{array}$ & $\begin{array}{l}\text { The share of a country's exports in } \\
\text { medium-high tech industries in the } \\
\text { exports of same the industries in } \\
\text { EU-28 (in percentages) }\end{array}$ & $\begin{array}{c}\text { Dep. } \\
\text { variable }\end{array}$ & \\
\hline High tech exp & $\begin{array}{l}\text { The share of a country's exports in } \\
\text { high tech industries in the exports } \\
\text { of the same industries in EU-28 (in } \\
\text { percentages) }\end{array}$ & $\begin{array}{c}\text { Dep. } \\
\text { variable }\end{array}$ & \\
\hline Exp_soph & $\begin{array}{l}\text { Initially, an index called PRODY is } \\
\text { constructed. It is defined as the } \\
\text { weighted average of the per capita } \\
\text { GDPs of countries exporting a } \\
\text { product, where the weights reflect } \\
\text { the revealed comparative } \\
\text { advantage of each country in that } \\
\text { specific product. } \\
\text { The export sophistication index is } \\
\text { defined as the weighted average of } \\
\text { PRODY for a country, where the } \\
\text { weights reflect the shares of } \\
\text { products in country's total exports } \\
\text { (Hausmann et al., 2007) }\end{array}$ & $\begin{array}{c}\text { Dep. } \\
\text { variable }\end{array}$ & $\begin{array}{l}\text { Own calculations based on } \\
\text { UNCTAD's database: } \\
\text { Merchandise trade matrix, } \\
\text { SITC revision } 3 \\
\text { (UNCTAD, 2014). }\end{array}$ \\
\hline Secondary_educ & $\begin{array}{l}\text { The percentage of population aged } \\
15 \text { and over who have attained } \\
\text { secondary education }\end{array}$ & + & Barro and Lee (2014) \\
\hline Tertiary_educ & $\begin{array}{l}\text { The percentage of population aged } \\
15 \text { and over who have attained } \\
\text { tertiary education }\end{array}$ & + & \\
\hline Schooling_years & $\begin{array}{l}\text { The average number of years of } \\
\text { schooling of the population aged } \\
15 \text { and over }\end{array}$ & + & \\
\hline Cognitive_skills & $\begin{array}{l}\text { Average test score in mathematics } \\
\text { and science, primary through end } \\
\text { of secondary school, all years } \\
\text { (scaled to the PISA scale divided } \\
\text { by 100) (averaged across time) }\end{array}$ & + & $\begin{array}{l}\text { Hanushek and Woessmann } \\
\text { (2009) }\end{array}$ \\
\hline Student_scores & $\begin{array}{l}\text { Mean scores of students at } \\
\text { international assessments (primary }\end{array}$ & + & Altinok et al. (2014) \\
\hline
\end{tabular}




\begin{tabular}{|c|c|c|c|}
\hline & $\begin{array}{l}\text { and secondary } \\
\text { (averaged across time) }\end{array}$ & & \\
\hline $\begin{array}{l}\text { Student_perfor } \\
\text { mance }\end{array}$ & $\begin{array}{l}\text { Adjusted mean scores of students } \\
\text { of secondary education in various } \\
\text { assessments (1965-2010) }\end{array}$ & + & Altinok et al. (2014) \\
\hline Patents & $\begin{array}{l}\text { Number of patent applications by } \\
\text { residents }\end{array}$ & + & WDI - World Bank (2014) \\
\hline FDI & $\begin{array}{l}\text { Inward foreign direct investment } \\
\text { stock (\% GDP) }\end{array}$ & + & UNCTAD (2014) \\
\hline Population & Total population (in thousands) & + & $\begin{array}{l}\text { Penn World Table } 7.1 \\
\text { (Heston } \text { et al., 2012) }\end{array}$ \\
\hline Labour_cost & $\begin{array}{l}\begin{array}{l}\text { Real unit labour cost index } \\
(2005=100)\end{array} \\
\end{array}$ & - & Eurostat (2014) \\
\hline $\begin{array}{l}\text { Transition_dum } \\
\text { my }\end{array}$ & $\begin{array}{l}\text { Whether the economy have gone } \\
\text { through transition }(1-\text { Yes, } 0 \text {-No) }\end{array}$ & - & EBRD (2014) \\
\hline Trans_indicator & $\begin{array}{l}\text { The average of a set of single } \\
\text { indicators - (normalized from } 0 \text { to } \\
\text { 1) }\end{array}$ & + & EBRD (2014) \\
\hline Econ_freedom & $\begin{array}{l}\text { Index of Economic } \text { Freedom } \\
\text { (overall score based on a set of } 10 \\
\text { factors) }\end{array}$ & + & $\begin{array}{l}\text { The Heritage Foundation } \\
\text { (2014) }\end{array}$ \\
\hline Unemployment & 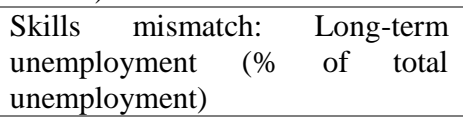 & - & WDI - World Bank (2014) \\
\hline Services_share & $\begin{array}{l}\text { Services, etc. , value added ( } \% \text { of } \\
\text { GDP) }\end{array}$ & - & WDI - World Bank (2014) \\
\hline Distance & $\begin{array}{l}\text { Distance from capital city to } \\
\text { Brussels (in km) }\end{array}$ & - & CEPII (2014) \\
\hline
\end{tabular}

Source: Author's calculations

Table A2. Descriptive statistics

\begin{tabular}{lccccccccc}
\hline & \multicolumn{3}{c}{ Full- sample } & \multicolumn{3}{c}{ TEs } & \multicolumn{3}{c}{ N-TEs } \\
\cline { 2 - 9 } Variable & Obs. & Mean & Std. Dev. & Obs. & Mean & Std. Dev. & Obs. & Mean & Std. Dev. \\
\hline Mid-high \& high & 3450 & 4.798376 & 9.32008 & 1330 & .7438904 & 1.257811 & 2120 & 7.341991 & 11.11761 \\
tech exp & & & & & & & & & \\
Mid-high tech exp & 1725 & 4.633252 & 9.158285 & 665 & .8908606 & 1.081199 & 1060 & 6.981072 & 11.02261 \\
High tech exp & 1725 & 4.9635 & 9.478894 & 665 & .5969202 & 1.397964 & 1060 & 7.70291 & 11.20538 \\
Exp_soph & 349 & 11665.96 & 3832.639 & 134 & 10265.91 & 4037.198 & 215 & 12538.55 & 3430.002 \\
Secondary_educ & 3450 & 60.05858 & 13.73341 & 1330 & 70.81586 & 10.4787 & 2120 & 53.30991 & 10.95088 \\
Tertiary_educ & 3450 & 18.9307 & 5.787445 & 1330 & 15.94188 & 5.312197 & 2120 & 20.80575 & 5.262548 \\
Schooling_Years & 3450 & 10.56545 & 1.191869 & 1330 & 11.11023 & .9687747 & 2120 & 10.22368 & 1.191806 \\
Schooling_Years^2 & 3450 & 113.0489 & 24.28718 & 1330 & 124.3749 & 21.4704 & 2120 & 105.9433 & 23.23692 \\
Cognitive_skills & 3600 & 4.923833 & .1830542 & 1370 & 4.929153 & .1916306 & 2230 & 4.920565 & .1775449 \\
Student_scores & 3760 & 570.4548 & 21.21084 & 1460 & 566.0342 & 19.62305 & 2300 & 573.2609 & 21.70148 \\
Student_perform- & 3180 & 564.3712 & 22.1829 & 1220 & 561.2037 & 22.25984 & 1960 & 566.3428 & 21.91044 \\
ance & & & & & & & & & \\
Patents & 3450 & 4512.962 & 10290.56 & 1330 & 529.0677 & 598.3724 & 2120 & 7012.292 & 12487.01 \\
FDI & 3450 & 3.471872 & 1.393738 & 1330 & 3.521384 & .6378107 & 2120 & 3.44081 & 1.704138 \\
Population & 3450 & 17823.64 & 22406.3 & 1330 & 9134.127 & 9272.683 & 2120 & 23275.07 & 26193.51 \\
Unemployment & 3450 & 37.5429 & 15.18352 & 1330 & 46.4015 & 13.02028 & 2120 & 31.98538 & 13.73891 \\
Econ_freedom & 3450 & 67.31971 & 7.317012 & 1330 & 63.26241 & 7.526873 & 2120 & 69.86509 & 5.898801 \\
\hline
\end{tabular}




\begin{tabular}{lccccccccc}
\hline Services_share & 3450 & 67.29414 & 7.281394 & 1330 & 62.16116 & 6.186593 & 2120 & 70.51436 & 5.948076 \\
Labour_cost & 3450 & 101.9594 & 4.739589 & 1330 & 102.2143 & 5.823309 & 2120 & 101.7995 & 3.902365 \\
$\begin{array}{l}\text { Distance } \\
\begin{array}{l}\text { Transition_dum- } \\
\text { my }\end{array}\end{array}$ & 3600 & 1041.277 & 581.3722 & 1370 & 1289.932 & 359.8802 & 2230 & 888.5157 & 636.2708 \\
Trans_indicator & NA & .3805556 & .4855909 & 1370 & 1 & 0 & 2230 & 0 & 0 \\
\hline
\end{tabular}

Source: Author's calculations

Table A3. Collinearity Diagnostics

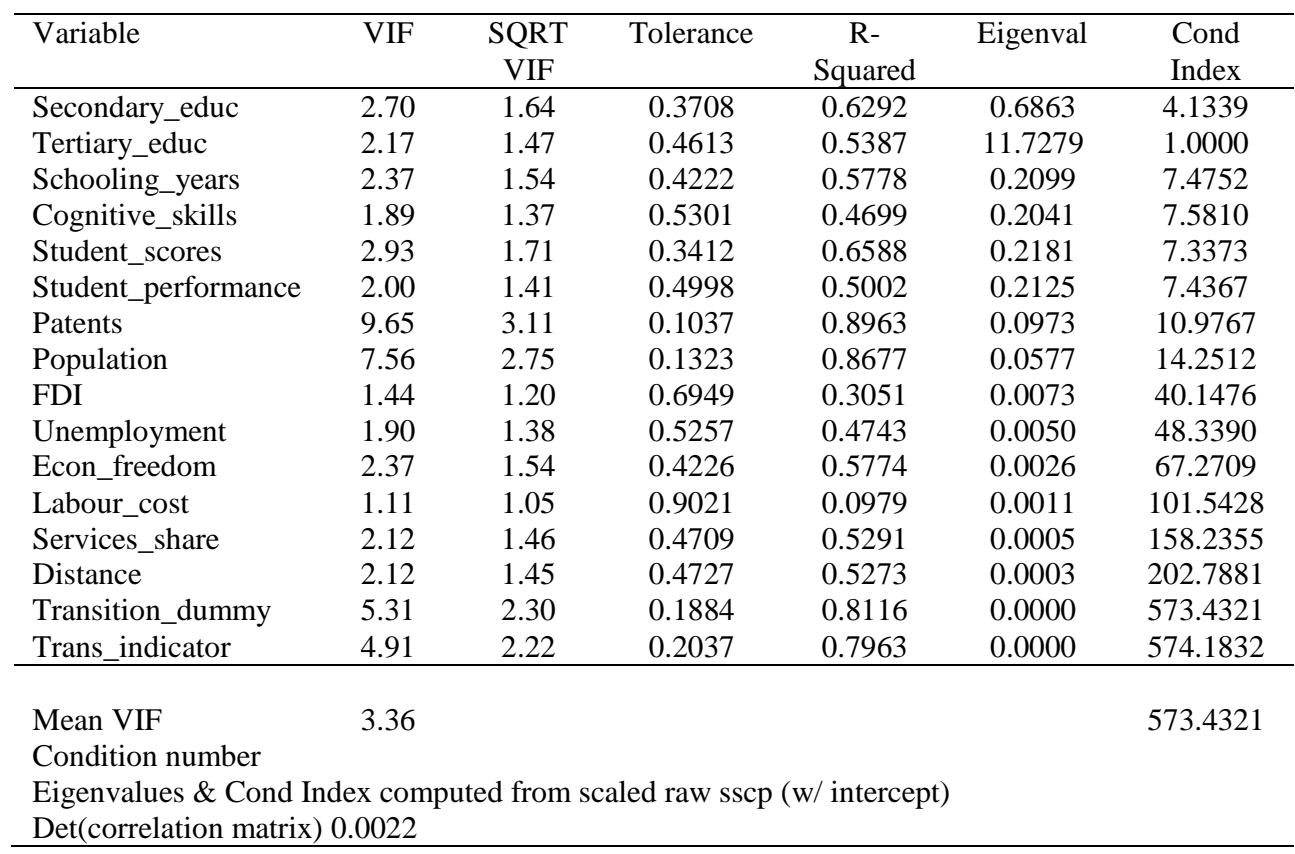

Note: Schooling years is included in a separate model specification from the other education attainment variables, hence its collinearity scores are computed separately. The same applies to the quality measures of education and transition variables. These variables are assessed in alternative model specifications.

Source: Author's calculations 
Table A4. IV Estimation Results for Export Market Share

\begin{tabular}{|c|c|c|c|c|c|c|}
\hline & \multicolumn{3}{|c|}{ Model Specification 1} & \multicolumn{3}{|c|}{ Model Specification 2} \\
\hline & $\begin{array}{c}\text { Full } \\
\text { sample }\end{array}$ & TEs & N-TEs & $\begin{array}{c}\text { Full } \\
\text { sample }\end{array}$ & TEs & N-TEs \\
\hline $\begin{array}{l}\text { Dependent variable in } \\
\log \end{array}$ & $\begin{array}{l}\text { Mid-high } \\
\text { \& high } \\
\text { tech exp }\end{array}$ & $\begin{array}{l}\text { Mid-high \& } \\
\text { high tech } \\
\text { exp } \\
\end{array}$ & $\begin{array}{l}\text { Mid-high } \\
\text { \& high } \\
\text { tech exp }\end{array}$ & $\begin{array}{l}\text { Mid-high } \\
\text { \& high } \\
\text { tech exp }\end{array}$ & $\begin{array}{l}\text { Mid-high \& } \\
\text { high tech } \\
\text { exp }\end{array}$ & $\begin{array}{l}\text { Mid-high } \\
\text { \& high } \\
\text { tech exp }\end{array}$ \\
\hline $\begin{array}{ll}\log & \text { of } \\
\text { secondary_educ }\end{array}$ & 0.326 & -0.229 & -0.363 & & & \\
\hline Log of tertiary_educ & $\begin{array}{c}(0.227) \\
1.401 * * * \\
(0.190)\end{array}$ & $\begin{array}{l}(0.753) \\
-0.417 \\
(0.525)\end{array}$ & $\begin{array}{c}(0.252) \\
0.376 \\
(0.234)\end{array}$ & & & \\
\hline Schooling_years & & & & $\begin{array}{c}-1.155 * * * \\
(0.376)\end{array}$ & $\begin{array}{c}-0.959 \\
(1.571)\end{array}$ & $\begin{array}{c}0.220 \\
(0.338)\end{array}$ \\
\hline Schooling_years^2 & & & & $\begin{array}{c}0.0567 * * * \\
(0.0176)\end{array}$ & $\begin{array}{c}0.0324 \\
(0.0671)\end{array}$ & $\begin{array}{l}-0.0114 \\
(0.0161)\end{array}$ \\
\hline $\begin{array}{l}\text { Log of } \\
\text { student_performance }\end{array}$ & $\begin{array}{l}1.511 \\
(0.980)\end{array}$ & $\begin{array}{c}0.721 \\
(1.862)\end{array}$ & $\begin{array}{l}2.244 * \\
(1.234)\end{array}$ & $\begin{array}{c}\text { 0.989 } \\
(1.001)\end{array}$ & $\begin{array}{l}1.135 \\
(2.020)\end{array}$ & $\begin{array}{c}1.398 \\
(1.292)\end{array}$ \\
\hline Log of patents & $\begin{array}{r}-0.0979 \\
(0.101)\end{array}$ & $\begin{array}{c}-0.631 * * * \\
(0.224)\end{array}$ & $\begin{array}{l}-0.0221 \\
(0.115)\end{array}$ & $\begin{array}{l}-0.0729 \\
(0.110)\end{array}$ & $\begin{array}{c}-0.702 * * * \\
(0.229)\end{array}$ & $\begin{array}{l}-0.0375 \\
(0.140)\end{array}$ \\
\hline Log of FDI & $\begin{array}{l}-0.0137 \\
(0.0140)\end{array}$ & $\begin{array}{r}-0.0749 \\
(0.154)\end{array}$ & $\begin{array}{l}-0.0150 \\
(0.0182)\end{array}$ & $\begin{array}{l}0.0205 \\
(0.0139)\end{array}$ & $\begin{array}{c}-0.0610 \\
(0.147)\end{array}$ & $\begin{array}{r}-0.00232 \\
(0.0187)\end{array}$ \\
\hline Log of population & $\begin{array}{c}-8.393 * * * \\
(0.622)\end{array}$ & $\begin{array}{c}-7.211^{* *} \\
(3.490)\end{array}$ & $\begin{array}{c}- \\
2.815^{* * * *} \\
(0.596)\end{array}$ & $\begin{array}{c}-8.573 * * * * \\
(0.603)\end{array}$ & $\begin{array}{c}-11.05^{* *} \\
(5.002)\end{array}$ & $\begin{array}{c}-1.789 * * * \\
(0.542)\end{array}$ \\
\hline Unemployment & $\begin{array}{l}-0.00144 \\
(0.00130)\end{array}$ & $\begin{array}{c}-0.00791 * * * \\
(0.00239)\end{array}$ & $\begin{array}{c}- \\
0.000131 \\
(0.00130)\end{array}$ & $\begin{array}{l}-0.00187 \\
(0.00129)\end{array}$ & $\begin{array}{c}- \\
0.00855 * * * \\
(0.00253)\end{array}$ & $\begin{array}{l}0.000289 \\
(0.00134)\end{array}$ \\
\hline Log of econ_freedom & $\begin{array}{c}0.362 \\
(0.290)\end{array}$ & $\begin{array}{l}0.347 \\
(0.534)\end{array}$ & $\begin{array}{l}-0.714 * \\
(0.370)\end{array}$ & $\begin{array}{l}0.744 * * \\
(0.295)\end{array}$ & $\begin{array}{c}0.474 \\
(0.530)\end{array}$ & $\begin{array}{l}-0.597 * \\
(0.354)\end{array}$ \\
\hline Services_share & $\begin{array}{l}0.0194 * * \\
(0.00946)\end{array}$ & $\begin{array}{l}-0.0227 \\
(0.0184)\end{array}$ & $0.0153 * *$ & $0.0230 * *$ & -0.0279 & $-0.0123^{*}$ \\
\hline Log of labour cost & $\begin{array}{c}(0.00946) \\
-0.00890 \\
(0.314)\end{array}$ & $\begin{array}{c}(0.0184) \\
0.496 \\
(0.465)\end{array}$ & $\begin{array}{l}(0.00727) \\
-0.0918 \\
(0.402)\end{array}$ & $\begin{array}{c}(0.00948) \\
-0.141 \\
(0.316)\end{array}$ & $\begin{array}{c}(0.0182) \\
0.604 \\
(0.468)\end{array}$ & $\begin{array}{l}(0.00728) \\
-0.190 \\
(0.409)\end{array}$ \\
\hline Trans_indicator & & $\begin{array}{l}1.013 \\
(0.875)\end{array}$ & & & $\begin{array}{c}0.897 \\
(0.905)\end{array}$ & \\
\hline No. of observations & 3,180 & 1,220 & 1,960 & 3,180 & 1,220 & 1,960 \\
\hline $\begin{array}{l}\text { R-squared } \\
\text { Tests } \\
\text { Kleibergen-Paaprk }\end{array}$ & 0.318 & 0.474 & 0.088 & 0.289 & 0.473 & 0.087 \\
\hline $\begin{array}{l}\text { LM statistic } \\
\text { (p. value) } \\
\text { Kleibergen-Paaprk }\end{array}$ & $\begin{array}{l}143.769 \\
(0.000)\end{array}$ & $\begin{array}{l}91.985 \\
(0.000)\end{array}$ & $\begin{array}{l}35.062 \\
(0.000)\end{array}$ & $\begin{array}{l}137.443 \\
(0.000)\end{array}$ & $\begin{array}{c}125.290 \\
(0.000)\end{array}$ & $\begin{array}{l}29.131 \\
(0.000)\end{array}$ \\
\hline Wald F statistic & 53.345 & 83.790 & 7.796 & 47.961 & 95.416 & 7.109 \\
\hline
\end{tabular}

Notes: Year dummies are included in the estimations but are not reported in the table. $* * * \mathrm{p}<0.01, * * \mathrm{p}<0.05,{ }^{*} \mathrm{p}<0.1$; Heteroskedasticity and autocorrelation robust standard errors are reported in parentheses. The HAC standard errors were obtained through the Bartlett (Newey and West) kernel option.

Secondary_educ, tertiary_educ, schooling_years, schooling_years ${ }^{\wedge} 2$, patents, and FDI are treated as endogenous. One period lagged values of these variables are used as internal 
instruments in the estimations. To assess the quality of the instruments, two tests have been conducted. The Kleibergen-Paaprk LM statistic represents an underidentification test which assesses whether instruments are correlated with the endogenous variables. The KleibergenPaaprk Wald F test shows if this correlation is weak. The results of these tests suggest that the estimated models are not underidentified; however, there might be a potential weak correlation problem in the N-TEs sample (F statistic $<10)$.

Source: Author's calculations

Table A5. IV Estimation Results for Export Sophistication

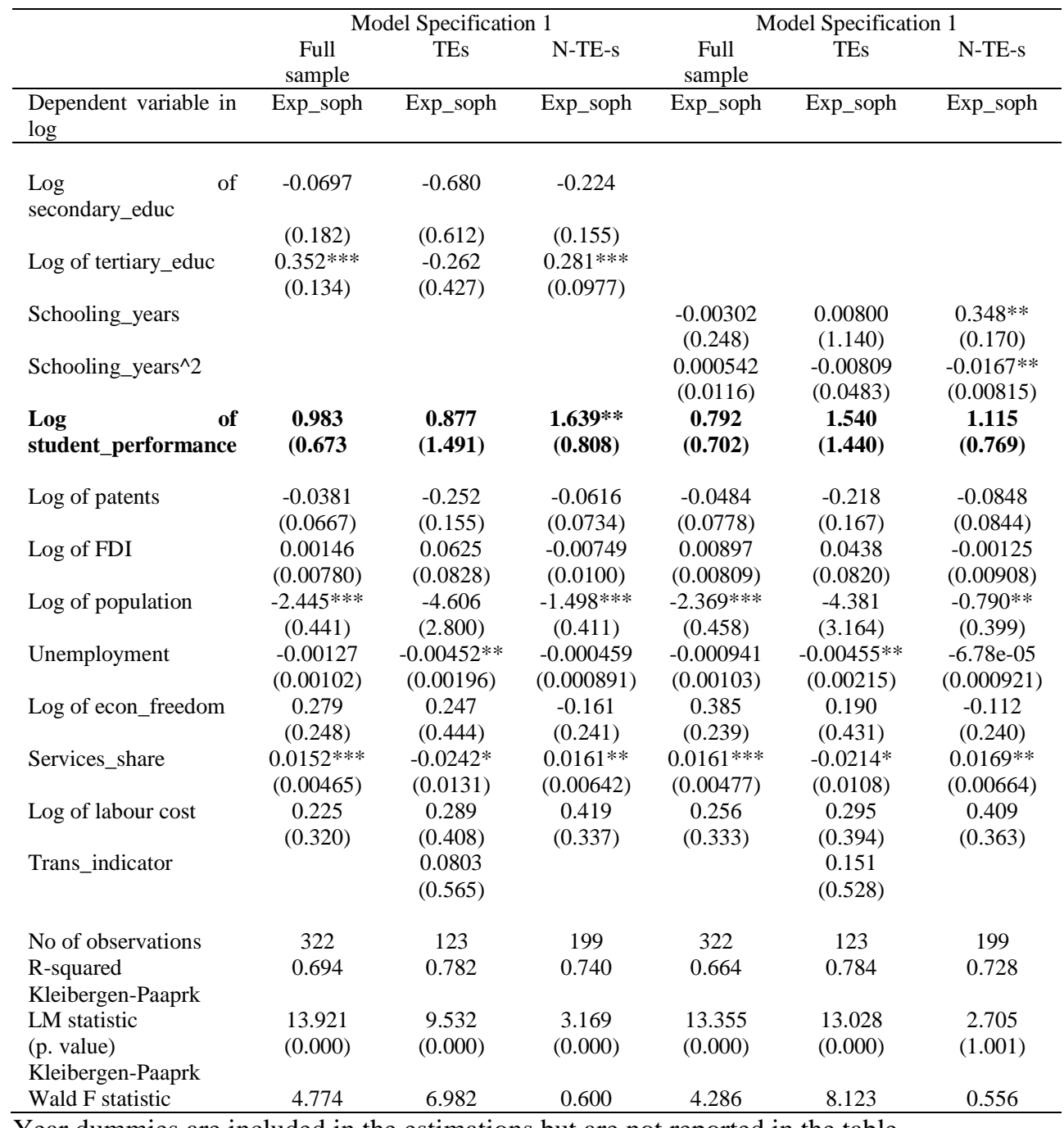

Year dummies are included in the estimations but are not reported in the table. 
$* * * \mathrm{p}<0.01, * * \mathrm{p}<0.05, * \mathrm{p}<0.1 ;$ Heteroskedasticity and autocorrelation robust standard errors are reported in parentheses. The HAC standard errors were obtained through the Bartlett (Newey and West) kernel option.

Secondary_educ, tertiary_educ, schooling_years, schooling_years ${ }^{\wedge} 2$, patents, and FDI are treated as endogenous. One period lagged values of these variables are used as internal instruments in the estimations. To assess the quality of the instruments, two tests have been conducted. The Kleibergen-Paaprk LM statistic represents an underidentification test which assesses whether instruments are correlated with the endogenous variables. The KleibergenPaaprk Wald F test shows if this correlation is weak. The results of these tests suggest that the estimated models are not underidentified; however, there might be a potential weak correlation problem (F statistic $<10)$.

Source: Author's calculations 